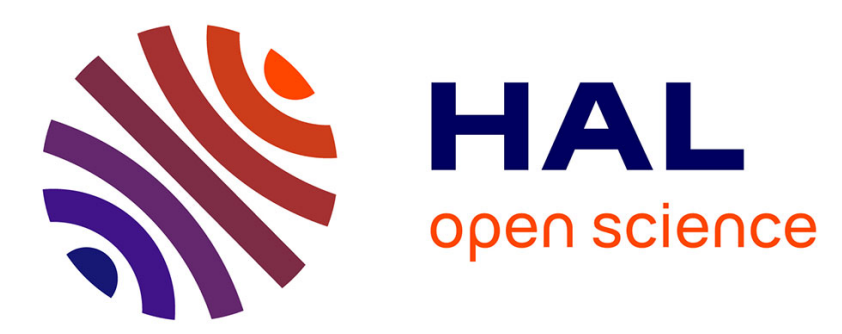

\title{
The politics of suspects' geo-genetic origin in France: The conditions, expression, and effects of problematisation
}

\author{
Joëlle Vailly
}

\section{- To cite this version:}

Joëlle Vailly. The politics of suspects' geo-genetic origin in France: The conditions, expression, and effects of problematisation. BioSocieties, 2017, 12 (1), pp.66-88. 10.1057/s41292-016-0028-x . hal01666332

\section{HAL Id: hal-01666332 \\ https://hal.science/hal-01666332}

Submitted on 15 May 2019

HAL is a multi-disciplinary open access archive for the deposit and dissemination of scientific research documents, whether they are published or not. The documents may come from teaching and research institutions in France or abroad, or from public or private research centers.
L'archive ouverte pluridisciplinaire HAL, est destinée au dépôt et à la diffusion de documents scientifiques de niveau recherche, publiés ou non, émanant des établissements d'enseignement et de recherche français ou étrangers, des laboratoires publics ou privés. 
This text was published under the reference:

Vailly, J. (2016) The Politics of Suspects' Geo-Genetic Origin in France: The Conditions, Expression, and Effects of Problematisation, BioSocieties, 12 (1), 66-88 (online 18 October 2016).

\section{The Politics of Suspects' Geo-Genetic Origin in France: The Conditions, Expression, and Effects of Problematisation}

\section{Joëlle Vailly}

Inserm, Institut de recherche interdisciplinaire sur les enjeux sociaux (Iris, CNRS, Inserm, EHESS, Université Paris 13), Bobigny, France.

vailly@ehess.fr

Tel : $33(0) 148388878$

Fax : $33(0) 148388862$

Joëlle Vailly is an anthropologist and a sociologist. She is a Senior Research fellow at the National Institute for Health and Medical Research (Inserm), in France. Her research interests concern social, political, and moral issues in genetics, biomedicine, and health.

This manuscript is comprised of original material that is not under review elsewhere, and the study on which the research is based has been subject to appropriate ethical review. The Author does not have any competing interest - intellectual or financial - in the research detailed in the manuscript. 


\begin{abstract}
Recently, genetics has given rise to changes in how people's origin is conceived. Forensics has started using some of these changes in the shape of new DNA-based tests aimed at determining suspects' geographic origin. This article analyses how recent practices in this field have been 'problematised' in France, in Foucault's sense of the term, and gives substantial weight to the country's historical and republican legacy. First, the launch of these genetic tests is examined, looking at the work of actors who helped create the preconditions for this problematisation but at the same time tried to deconstruct it. The paper goes on to focus on how this problematisation is expressed, questioning the arguments used particularly by its opponents who ground their stance in history, law, and science, while also invoking ethical and political concerns regarding data use. Finally, current state regulations on the matter are outlined, showing how 'points of problematisation' have been construed in terms of prohibition. The article concludes by underlining the internal tensions (the 'knot') of the problematisation process, showing how it highlights changes in contemporary notions of origin and the types of subjects it produces. More generally, the implications of this study for social science research on origin and on the life sciences are also discussed.
\end{abstract}

Keywords: geographic origin; genetics; problematisation; anthropology; forensics; France. 
Since the human genome was sequenced at the turn of the millennium, lively biomedical debates on 'geographic', 'ethnic', or 'racial' origin grounded in genetics have arisen (Burchard et al., 2003; Cooper et al., 2003; Bamshad et al., 2004; Collins, 2004). ${ }^{1}$ Most social science studies in this domain concern laboratories or healthcare (in particular, Abu El-Haj, 2007; Fullwiley, 2007; Social Studies of Science, 2008; Fujimura and Rajagopalan, 2011; Kahn, 2013; M'charek, 2005; Readon, 2005 ; Wade et al., 2014). ${ }^{2}$ These studies shed very productive light on the relationships between the biological and social aspects that inform human taxonomies. However, the practices resulting from these debates and changes have now extended beyond the scope of laboratories and relationships with patients. In forensics, human samples have customarily been categorized as 'Black' or 'White' without this necessarily being underpinned by racial theories (Sauer, 1992). The forensics field has begun to draw on the changes described above by using a new technique that differs from the traditional tests known as DNA profiling (also called DNA fingerprinting, 'empreintes génétiques' in French), which have been used for the past twenty years, particularly in the United States and in Europe. ${ }^{3}$ The aim of DNA profiling is to identify a suspect by comparing a person's DNA profile with, for example, a trace left at a crime scene (just as with traditional fingerprints). The aim of the new technique is, instead, to predict a suspect's geographic origin, potentially in addition to eyewitness testimony. Approximate geographic origin (by continent or sub-continent) established on the basis of DNA traces has been used in several hundred police investigations in the United States, and was also used in the investigation into the 2004 Madrid terrorist attacks (Sankar, 2010).

While forensic DNA tests aimed at determining origin have garnered increasing attention from the social sciences, only a very limited number of studies have addressed the issue of using these tests. They have mainly taken an anthropological, legal, or bioethical approach. Some of these, conducted in the United States, have underlined that such tests fall short of 
legal and scientific standards for trial admissibility (Fullwiley, 2011) and pointed to the problems they pose in terms of categorization, as well as the potential political and ethical issues they raise (Ossorio, 2006; Sankar, 2010). Other studies, carried out in the Netherlands, have shown that 'race' is a relational object, in that it is simultaneously factual and fictional, or that DNA profiles are not neutral but normative and part of a collective configuration (M'charek, 2008; 2013). In the Netherlands too, another study has analysed the regulatory issues involved in the use of such tests as well as the extent to which they should be allowed (Koops and Schellekens, 2008). My contribution to this area of research consists in showing how these practices spread and give rise to debate in different social worlds. More precisely, I address, on the one hand, a subject that until now remains unexplored in this field, namely, the way in which these innovations are problematised in the public space. On the other hand, my focus on France, a country where the genetics-driven transformation of origin has scarcely been studied, takes the question of its historical and social context seriously.

Looking first to the notion of 'problematisation', this concept has been used by a series of social science researchers within various analytical frameworks (Vailly, 2013). These studies have analysed, for example, the social construction of public problems (Berger and Luckmann, 1966; Hilgartner and Bosk, 1988), putting public policy problems on the agenda (Kingdon, 1984), and how problems are constructed, in Michel Foucault's sense of the term (1984). My focus here is on the latter and it is important to emphasize that Foucault uses the term 'problematisation' in several ways (Gros, 2014). In a relatively limited sense, he uses it to refer to practices that 'pose a problem' or 'raise questions': 'For a domain of action, a behaviour, to enter the field of thought, it is necessary for a certain number of factors to have made it uncertain, to have made it lose its familiarity, or to have provoked a certain number of difficulties around it' (Foucault, 1984, p. 388). This approach is productive in highlighting 
how a previous practice can 'lose its familiarity' and become 'problematised'. As an analytical method, this seems particularly appropriate for looking at legal and police investigations given that, in this context, oral testimony about origin or 'ethnicity' has long been a commonplace variable of physical appearance. In fact, origin is the most common descriptive element used in eyewitness statements and has been described elsewhere as 'a race-attentive means of differentiation' (Fox, 2010, p. 70). My first hypothesis is that the way genetic tests of origin - unlike oral testimony - have been problematised in France is of heuristic value for analysing changes ('[loss] of familiarity') relating to origin.

In a broader sense, Foucault (1989, p. 296) defines problematisation as 'the set of discursive and non-discursive practices that make something enter into the play of the true and false and constitute it as an object for thought (whether under the form of moral reflection, scientific knowledge, political analysis, etc.)'. As this quotation shows, studying problematisation has the advantage of taking into account the scientific, political, and moral dimensions of practices. However, Foucault also explains that, depending on the issue at hand, emphasis will be given to one particular dimension (in his own research, this was the scientific dimension when he studied madness, the political dimension when he studied law and order, and the moral dimension when he studied sexuality). While I take all three dimensions seriously here, this analytical framework does require paying particular attention to the political dimension of questions linked to law and order.

At the end of his life, Foucault (1986) extended the notion of 'problematisation', looking at how sexuality was construed as a moral problem. In doing so, he asked important questions about how we 'direct our own conduct' as 'subjects' (Gros, 2014). Of course, it is also important to underline that these 'subjects' who are able to adopt a particular moral stance or engage in particular moral behaviour are not timeless individuals. Contrary to Sartre's conception of the subject, for Foucault these individuals are formed over time by various 
processes (Foucault, 2011 [1978]. ${ }^{4}$ Similarly, according to this analytical framework, scientific categories are rooted in these processes and this is why they are not predetermined: they are shaped during the problematisation process. ${ }^{5}$ My second hypothesis is therefore that problematisation can also tell us about the kind of individual 'subject' that is produced by this process. A particular actor can problematise a question in a variety of ways, by emphasizing one dimension (scientific, moral, political, etc.) rather than another. The three components of problematisation (the problem + science/politics/morality + the 'subject') offer productive analytical tools for the study presented in this article.

To turn now to my focus on France, it is important to provide some historical background explaining how questions of so-called ethnic or racial difference are broached in the French context.

In France, the Declaration of the Rights of Man and of the Citizen in 1789 heralded a break with all forms of segregation based on race, religion, or ethnic origin, on paper at least (Noiriel, 1996). Unlike in the United States, for example, being French was traditionally considered to mean belonging to the nation, in a political sense. This nation was theoretically indifferent to skin colour and diametrically opposed to any form of racialization (Ndiaye, 2006). This explains why today in France, almost no official racialized data are collected or used by the State and why the principles of non-discrimination, equal rights, and the unity and indivisible nature of the French nation figure prominently in French law (Canselier and Desmoulin-Canselier, 2011). However, the Republican model only reflects one aspect of the country's history. As others have noted, 'the tension between principles of inclusion and practices of exclusion ... informed the republican project since the Revolution' (Chapman and Frader, 2004, p. 3). Belonging to the nation was grounded on a republican ideal that was ambiguous from the outset: while in theory it applied to everyone, in practice it was limited due to discrimination. For centuries, France saw the development of the two main forms of 
European racism - anti-Semitism and prejudice against 'non-Whites' (Chapman and Frader, 2004). Historian Ndiaye (2006, p. 46) reminds us that 'the French Empire developed [over centuries] by subjugating populations defined as non-White ... to whom citizenship was denied... [ In the colonies], being French meant being White'. Moreover, as he explains, with the arrival of half a million black soldiers and workers from the time of the First World War onwards, fear of racial intermingling shifted from the colonial world to mainland France, and anxieties about race increased. It was only in the 1930s that the reluctance to use the word 'race' became widespread among republican elites. The first anti-racist law was passed in 1972, heralding the end of the republican tradition of no state intervention in matters of race (Noiriel, 2006). In short, so-called racial questions have always been present in France but are now increasingly expressed in the public space, despite the country's emblematic position as 'colour-blind', a legacy of the Revolution (Fassin and Fassin, 2006).

In light of these definitions and this contextual information, the questions addressed in this article can be expressed in the following terms: how and why have the new origins resulting from genetic tests in forensics been 'problematised'? In other words, what '[loss] of familiarity' have these tests produced which has resulted in this problematisation? What technoscientific practices, what political analyses, and what moral questions do social actors call upon in this regard? And finally, how has the French historical and republican legacy influenced the way genetic origin is problematised? For the social sciences, the key issue is unpacking the mechanisms of these processes in a context where French society is increasingly becoming the locus for discourse and debate surrounding origin. On a theoretical level, the aim is to think critically about the various ways in which 'problematisation' might be put to productive use (as opposed to simply applying the concept unilaterally).

In order to answer these questions, I will analyse how recent practices relating to suspects' origin based on DNA analysis have been problematised in France. I will begin by examining 
the launch of these tests. In doing so, I will look at the work of actors who, on the one hand, helped create the preconditions for problematising these tests by producing controversial categories of origin and, on the other, tried to deconstruct the problematisation that ensued. I will then turn to how this problematisation was expressed, based on its opponents' arguments, which drew on history, law, and science, as well as ethical concerns and policies on data use. Finally, I will discuss current state regulations, showing how crime, origin, and the private nature of DNA have come together to create a situation that is politically sensitive and how what Foucault calls the 'points of problematisation' have been construed in terms of prohibition. In conclusion, I will underline the internal tensions (the 'knot') of the problematisation process, showing how it highlights changes in contemporary notions of origin and in the types of subjects it produces. More generally, the implications of this study for social science research on origin and on the life sciences will also be discussed.

\section{Outline of the study}

This study is part of a broader project on the social issues at stake in the use of genetic analyses by the law and the police in France. I began this research with 15 interviews conducted between 2012 and 2014 with judges and prosecutors, political officials, and managers in biotechnology companies (biologists and doctors). The respondents were included in the study based on their active participation in this debate. The interviews, which lasted 2 hours on average, were fully transcribed afterwards. They focused on the respondents' career path, the use of tests of origin in France, and their position on the topic. I then analysed all the press cuttings and audio-visual archives identified on the topic in the Europresse database and at the French national audio-visual institute (INA) respectively. The interviews and data from the different documents were coded by theme in order to identify the different dimensions of the problematisation (scientific aspects, political stakes, moral 
questions, legal framework, etc.). A common method for qualitative surveys was applied that consists in adjusting analysis as investigations go forward (Glaser and Strauss, 1967). It is important to underline that this study was relatively difficult to carry out, as the respondents were sometimes reluctant to discuss tests of origin with me. This can be understood as a result in itself, illustrating the problematisation that I was analysing.

\section{Promoting tests of origin: producing categories and deconstructing problematisation}

As I specified in my introduction, problematisation is more than just a set of ideas or mental images; it is produced through practice (Bacchi, 2012). Examining the launch of these tests to infer suspects' geographic origin is useful in understanding this. First, we will see the work done by various actors who helped produce the preconditions for this problematisation by creating potentially controversial 'geographic' categories. Second, we will look at how the same actors went on to try and deconstruct this problematisation by putting forward various arguments to justify these tests and make them seem commonplace.

\section{The roots of problematisation}

Before looking at the specific issue of genetic tests of origin, it is important to first consider genetic analysis in French forensics more generally. At the end of the 1990s, France set up a database of conventional DNA profiles - which are different from the more exploratory phenotyping, as we have already seen. Today, the country's database is the second largest in Europe (article in preparation). Nationwide, fifteen public and private centres are authorized to analyse DNA profiles. An official ministerial order stipulates which 'genetic markers' (i.e. small sequences of DNA) can be used for this purpose. ${ }^{6}$ French law stipulates that the DNA tests used for conventional DNA profiles must be based on 'non-coding' DNA markers. ${ }^{7}$ 
Non-coding DNA, by definition, makes up 90-95\% of human DNA and is not directly involved in producing proteins.

Biotechnology company [X], composed mainly of biologists, was one of the first to offer genetic analyses for legal ends in France in the 1990s. In the following years, it grew rapidly to become one of the main private companies in this sector in France. The main founder of the company, Doctor [Y], who died accidentally shortly after I began my study, was a renowned doctor and molecular biologist. He considered France to be 'overcautious' in terms of genetics, as he stated in the media. Nonetheless, both this manager and his company $[\mathrm{X}]$ met with a large measure of agreement, including among judges who, as we shall see, contributed to problematising the tests of origin offered by the company in the 2000s. It is important to note here that, unlike in the United States or Great Britain, judges play an investigative role in legal proceedings in France. ${ }^{8}$ More generally, company $[\mathrm{X}]$ has the reputation of being reliable and investigating judges and prosecutors have no qualms in entrusting their samples to the company for analysis. However, this good reputation may have been tarnished somewhat by the innovative test the company launched at the end of 2006, which they called a 'test d'orientation géo-génétique' (TOGG - indicative geo-genetic test). As its name indicates, this genetic test provided an indication of a suspect's geographic origin, thus orienting legal or police inquiries in that direction. The process consisted in analysing DNA traces left by a culprit at a crime scene and determining 'genetic markers" ${ }^{\text {'9 }}$ (chosen on the basis of a compilation of the relevant scientific literature) that were more common amongalthough not specific to - certain populations. These markers are found in so-called noncoding DNA and this proved important in the events that followed. Three populations (Europe, Sub-Saharan Africa, and East Asia) were used as references for the statistical study of the distribution of variations and the results provided by the test indicated whether a person was 'probably' of European, Asian, or African origin. It was also supposed to indicate if the 
person belonged to an 'intermediate' category, i.e. resulting from 'mixtures' with a 'contribution' from the three populations of reference. ${ }^{10}$ To illustrate what was being proposed, the current head of the company used an actual case:

For example, there was a young girl who had been killed - raped and killed. So we had DNA from a semen stain. And so we had said it was a person who had a mixture of Caucasian DNA and Sub-Saharan DNA. And so the police had a list of 500 suspects, and among the 500 suspects they took samples from everyone, whether they were White, Black, or Yellow, but they prioritized those who came from a region where there could be a mixture like that. So it could be North Africa, it could also be the Caribbean. There are regions in the world like that, where there are mixtures, islands, the Caribbean, or Reunion, where there have been lots of population mixes. And it turned out that the perpetrator was from... (She looks on her computer). Originally from Cape Verde. So, from the DNA, we'd said it was someone who came from a place where there was a mixture of Black and Caucasian populations. And we weren't wrong.

It is important to note how the respondent's discourse shifted within the same conversation between classifications based on geography (Europe, Africa, North Africa, the Caribbean, Reunion), genetics (Caucasian), and colour (White, Black, Yellow). Incidentally, this shifting terminology calling on both colour and geographic zone has existed since the birth of physical anthropology (Hacking, 2005b). These variations in terminology sow the seeds for problematisation insofar as they open the door to ambiguous interpretations that may be geographic and therefore relatively neutral, but which also resonate with commonly held racial categories, and are therefore potentially controversial. On the one hand, these tests are part of the inception of what sociologists call 'genome geography' (Fujimura and Rajagopalan, 2011), referring to links drawn between genome sequences and geographic sites 
defined as people's places of origin. On this point, it is worth noting that the geography in question is somewhat vague ('North Africa, the Caribbean... Cape Verde') and therefore still a long way from the stated goals of geneticists. However, this does not prevent biologists from using these categories while remaining aware of their limitations (Smart et al., 2008; Skinner, 2011). On the other hand, as several researchers have indicated (Fullwiley, 2008; Ossorio and Duster, 2005), the notion of origin in terms of continents may well revive older eighteenth-century notions of 'race' given that the ideas of geography and race can overlap topographically (see the parallel drawn above by the respondent between 'Africa, Europe, Asia' and 'Black, White, Yellow'). Even though it is difficult to define these different categories, they are still nonetheless assigned to 'populations' with potential racial connotations. From as early as the eighteenth century, one scholar recognized the absence of clear delineations between groups while, at the same time, defending the idea that 'races', as they were called at the time, had a scientific basis (Abu El-Haj, 2007). We can see here the roots of a form of problematisation based on the production of ambiguous geographic categories that also align with commonly held racial classifications.

Moreover, as mentioned in the introduction, problematisation tackles the dimension of "what is true and what is false', to use Foucault's words. In the case of these tests, this can be translated into the question of how scientific they were. The TOGG included a large number of genetic markers, based on population studies, and a statistical approach, combining both the scientific character of mathematics and specific knowledge brought by biologists. The test was therefore scientific in nature. However, as the current company director stated in an interview, no statistical figures were provided for the probability of the suspect's origin: 'We said: 'he is probably of $\mathrm{X}$ origin, etc.' ... We didn't give any probabilities; we didn't mess around with statistical information. Because, quite simply, we didn't have that information'. When a geneticist stated during a radio debate that: 'The prediction will be made with a very 
large margin of error', doctor [Y] responded: 'That's exactly what we say. It's statistical, it gives a direction. We don't say anything more'. In short, the approach used statistics and was based on a large number of markers but, at the same time, it was not very precise. More specifically, it was honest enough not to fall into the trap of providing simplistic calculations giving the illusion of greater precision. As Duster has summarized (2011, p. 107) 'to say that someone is 85 percent African, we must know who is 100 percent African', without forgetting that genetic variation within the African continent is substantial and the population serving as a reference point is always based on an arbitrary choice. ${ }^{11}$ In short, unlike biomedical studies where a precise percentage of markers is used (Fullwiley, 2008), in this case, the genomic approach generated 'probable' results and specific statistics were erased in the results provided. We will see further on how the judges and prosecutors interviewed perceived the scientific nature of the tests and how it was a potential source of problematisation.

\section{Making tests of origin commonplace}

In 2008, Doctor [Y] stated in an online media source that he was fully aware of 'the highly sensitive nature' of the TOGG. We will come back to this. Paraphrasing what Deacon, following Foucault, calls the 'deconstruction' of problems (2000, p. 140) - i.e. attempts 'to subvert what has been problematised' - one might say that the company managers did everything they could to try to deconstruct the problematisation of these tests. In this spirit of deconstruction, the company managers were careful to clarify several points with regard to the TOGG.

First, the categorization that the tests involved was justified by the fact they were useful. For example, Doctor [Y] stipulated in a television interview that: 'These are elements that provide assistance in investigations that obviously aren't about a stolen moped; they're for severe crimes, things that are really really serious.' This manager put forward the pragmatic 
argument of the test's usefulness, also calling upon emotions by emphasizing the serious nature of the offences in question. Pragmatic justification was therefore one initial attempt at deproblematisation on the part of the company. More specifically, practices and discourse were used as a 'solution' (Foucault, 1984; Rabinow and Rose, 2003) to the 'problem' posed not by genetic origin but by unsolved crime.

Second, in the eyes of the biotechnology company, there was nothing specific about these tests. '[The TOGG] does not provide much more information than an eye-witness report. Someone attacks someone else in the street, you'll say, he was Black, he was 1.8 metres tall ... We don't give much more information than that' explained a representative in an interview. For the company managers, the aim was to deploy commonly used and commonly understood labels to deconstruct the problem posed by the TOGG. They deliberately left the genetic approach in the background. This analogy with eyewitnesses, which has been drawn by other geneticists in biomedical literature (Kayser, 2015), was also used by one of the prosecutors I interviewed, as we will see a little further on.

Third, the company managers underlined the fact that the information provided by the tests concerned geographic origin not physical appearance. This was clearly an attempt to stem accusations about stigmatizing people or groups in a context where the issue of what Ndiaye (2006) has called ‘discrimination mélanique' (literally ‘melanic discrimination' or discrimination according to skin colour) was increasingly important. ${ }^{12}$ One manager stated in an interview: 'We didn't provide anything about the person's physical appearance. We said: he comes from this region in the world'. These managers linked this assertion to the fact that the TOGG was based on 'non-coding' genetic markers, as mentioned previously. For them, given that these markers did not correspond to genes, the TOGG could not provide 'any information about skin colour, eye colour, hair colour, face shape, or even any potential genetic diseases', as Doctor [Y] stated on television. However, the shift from genotype 
(DNA) to phenotype (appearance) was inherent in the logic of the approach itself, given that the whole aim was to provide practical indications about suspects' appearance to the people investigating crimes. The geneticists' argument that the tests did not indicate appearance was fragile to say the least and I will come back to this later when I look at the point of view of the TOGG's opponents.

Finally, the company managers took the time to publish a 'Charte d'utilisation du TOGG' [Charter for the use of TOGG], with an ethical dimension stating that the test was 'not ... a determination of race, especially given that this notion is very vague in human genetics'. As outlined in the introduction to this paper, such discourse should be understood in its social and historical context as it echoes the pro-universalism stance of French law and deliberately avoids using the terms 'race' and 'ethnicity' (Canselier and Desmoulin-Canselier, 2011). The managers therefore did not enter into the on-going debate among geneticists (above all in the United States) regarding whether or not races existed. Instead, they chose to place their discourse at the level of origin and ancestry rather than race (Ossorio, 2006; Fujimura and Rajagopalan, 2011). They claimed that they took 'origin' into account while avoiding racism (Brattain, 2007) and that there was absolutely no question of establishing hierarchies between groups of population, such as those that prevailed during the periods of colonization or slavery when racial theories developed (Wade, 2014).

In short, the '[loss] of familiarity' in terms of geographic origin came from the fact that, on the one hand, geneticists stated that races did not exist on a genetic level while, on the other, offering a technoscientific means through which to distinguish people according to their origin - a means that was based on European, African, and Asian parameters and that had the more or less openly stated aim of providing an indication of appearance. Certain authors describe this ambiguity as the 'absent presence of race' (M'charek et al., 2014; Wade et al., 2014). To take this idea further, the tension between these two positions can be said to have 
both generated the problematisation of the issue and been used to try to deconstruct it.

Moreover, the effects of this problematisation in terms of what Foucault called the 'true or false', in other words how 'scientific' the test actually was, seem to have raised immediate questions among the actors involved ('the prediction will be made with a very large margin of error') and we will come back to this. Finally, from the point of view of the subjects, at this stage, the people directly concerned by the tests, i.e. the suspects, were not subjects yet. This sets the present case apart from other genetic tests where the notion of 'biological citizenship' has been mobilized, with citizens requesting the tests rather than having them imposed 'from above' (Rose, 2007). ${ }^{13}$ In the case of the TOGG, it concerned people who were by definition anonymous as the aim was to determine to which more or less vague group (e.g. North Africa, Reunion, Cape Verde, etc.) an unknown suspect belonged. As for the people promoting the tests, they attempted to position themselves as ethical subjects (through their Charter, by taking distance from the notion of 'race', etc.). The people in a position to use the tests will now be discussed in some detail.

\section{Potential users of the test: how problematisation was expressed}

Let us turn to how the problematisation of the TOGG in France was expressed, by examining the arguments used by its opponents and proponents. The judges and prosecutors I interviewed took one of three potential stances: some were opposed to the tests for reasons related to history, to the law, and to the test's reliability; some were doubtful about the test, for reasons related to its usefulness, to the law, and to its reliability; and others were in favour of the tests, for reasons related to its usefulness. 
Let us look first to the arguments put forward by the people who were opposed to the tests. In the judicial context in France, analysis of DNA traces is often funded by the Ministry of Justice. The biotechnology company therefore began by canvassing members of the judiciary, informing them of the possibility of this new technique, which cost several thousand euros, and attempting to convince them of its value. One of the company's marketing representatives had the chance to vaunt its merits in 2007 during a meeting of ten to twelve judges in Lyon, which is the second largest city in France in terms of inhabitants. According to the judges' account of the meeting, it was turbulent, particularly due to one of the judges there who expressed his opposition in no uncertain terms. His reasons will be outlined further on. This judge was the former national secretary for the Syndicat de la Magistrature (SM), a clearly left-wing trade union that was created during the events of May 1968 and that is now the second largest judiciary trade union in France. Thanks to his union activities, he had experience in dealing with the media and so he contacted a young journalist with a view to using the press to try and block the sale of the TOGG. This strategy could clearly be considered an attempt at 'external mobilization', in other words using the media to call upon public opinion when no institutional recourse is available (Garraud, 2004). As he said in an interview: 'A scientist must have broad general knowledge and ethics when he puts a procedure in place and [must ask himself]: is this procedure acceptable in terms of society's taboos or is it unacceptable?... I'm sorry, but I'm not here to live in a society where we classify wanted criminals according to their skin colour'. An article therefore appeared in 2008 in an online newspaper reporting a dozen uses of the TOGG by French judges and prosecutors and underscoring the secrecy surrounding its use. This secrecy spoke to the opposition that such analyses had the potential to generate on a political/moral, legal, and scientific level. 
As I have just suggested, the first kind of argument used by opponents was political and moral in nature. This stance warrants further contextualization, given that in 2008 there had already been much alarm in France about the substantial development of databases ('fichiers', a word that means both 'files' and 'database' or 'registry') compiled for police and legal purposes. Such databases fall too far outside the remit of this article to discuss them in detail here, but suffice it to say that they were considered likely to infringe on personal freedom (Mattelart and Vitalis, 2014). The first argument against the TOGG, and the most important in the eyes of its opponents, was the risk of discrimination and of compiling fichiers of a racial nature. In the French context, reticence towards keeping this sort of information on file has to be understood in light of the country's specific WW2 history and the Jewish files ('les fichiers juifs') that were kept during that period. The judge from Lyon who was most against the use of tests of origin in the legal context used the term 'problématique' [in the sense of the key issue at stake], echoing the notion of problematisation. He explained in an interview that: I said [to the company representative who had come to promote the TOGG]: 'You're necessarily going to create a database [un fichier].' And he said: 'Well, yes, it will be a database [fichier] of wanted criminals, where we'll put a certain number of elements'. And I said: 'Have you thought about that, in your laboratory, about the issue at stake [problématique] in what you're implementing, particularly in terms of discrimination, of discriminatory files [fichiers]?' And he said: 'Well, no.' And then I told him that it was horrendous, that if he had a little historical knowledge, particularly about the Second World War, the Jewish files, it might ring a few bells.' The managers at company [X], for their part, claimed that they 'would not create any databases with the samples entrusted to them' (Charte d'utilisation des TOGG). Despite these reassuring statements, other leaders from the SM or human rights organizations like the Ligue des Droits de l'Homme (Human Rights League) sided with the judge, taking a hypothetical 
perspective looking at the potential dangers should a more or less authoritarian state rise to power. In interviews, judges and prosecutors said for example: 'If thanks to [this test], we make lists or files [fichiers] according to category of population, then that poses a problem for me. ... It's a real political issue. ... Morally, ethically, I'm against [TOGG]'; 'It's very easy to see what this would be used for if there were no longer any democracy and if history took a tragic turn, as it has in the past. Underlying all this, there's the deportation of the Jews.' While many practices linked to origin have the potential to generate problems of stigmatization and discrimination, particularly in the legal and police spheres (Welch, 2007), the question of the databases compiled by laboratories and the potential political uses that could be made of them make this dimension particularly acute here. It should be noted that the purpose of this possible database created by the laboratory is not clear, which reflects the fact these practices are in their infancy. At all events, at this stage it would have been more a set of data kept by the laboratory than a national database managed by the police, and would have been more limited than the national database of DNA profiles, which has 3.5 million profiles in France (Vailly et al., 2016). However, the divide concerning the nature of DNA tests themselves was clear. We have already seen how the company managers sought to deconstruct the problematisation surrounding the test by making it seem commonplace. Conversely, one prosecutor explained in an interview: 'You draw up an expert report, you're told: "The bloke is of whatever origin", ... that's confidential to the investigation, ... it's not public. It doesn't affect social cohesion or discrimination... it doesn't create categories of populations, it's very different.' In other words, when elements regarding a suspect's origin are provided through oral eyewitness statements, they remain confined to the investigation and as such are confidential; when they are established by a laboratory, however, the laboratory in question is likely to organize them into databases that could be disseminated and that might lend scientific legitimacy to tools of discrimination. 
This first series of arguments against the TOGG calls for several remarks. First of all, the position held by opponents to the TOGG should be considered in terms of the context outlined in my introduction, i.e. the fact that unlike in the United States or in Great Britain, for example, collecting 'ethnic' or 'racial' data in France is strictly prohibited on the grounds of the country's republican universalism. ${ }^{14}$ Second, WW2 clearly appears as a decisive factor in understanding how this problematisation operated in France: the history of Nazism has reinforced the rejection of ethnic or racial identification in French political culture (Chapman and Frader, 2004). Incidentally, such topics have become even more sensitive recently due to the rise in support for the far right in France. Finally, as we have seen, analysing problematisation also requires examining the types of subjects it produces. In general, while it is true that the ethics of science is no longer left to researchers alone (Fischer, 2012), this becomes even more vital when science ethics lies at the intersection between various social spaces such as the legal system and the media. It should be noted that, in this regard, the actors did not only frame the issue in ethical terms, they also framed it just as much in political terms ('it's a real political issue ... Morally, ethically...' said one prosecutor). This situation is different from the situation in Great Britain where traditional DNA databases (as opposed to tests of origin per se) are classified according to a person's origin (Skinner, 2011). Unlike the issues surrounding these databases in Great Britain, in the French case at hand, there was no tendency to consider them as 'belonging to the domain of the expert community of bioethicists rather than being matters of politics and public interest' (Skinner, 2011, p. 61). In short, these French social actors underlined the specific nature of DNA tests in terms of the files that would be compiled, but did not conclude that the issues they raised fell under the remit of bioethics experts or were apolitical in nature, quite the contrary. The judges and prosecutors opposed to these tests seemed to have interiorized the risks of them becoming public. For Toom (2012, p. 152), 'when jurisdiction over a body is transferred from an 
individual to agents of power like police and medics, those bodies transform from "private bodies" into "public bodies"". We can take this point of view further and underscore that, in this context, these public bodies were considered within a political configuration, whether current or feared (i.e. a potential future authoritarian State). In other words, it was a question of the ethics and politics of how data is or could be used. In short, we were dealing with political and ethical subjects who were just as concerned about their own role in society ('I'm not here to live in a society where we classify wanted criminals according to their skin colour') as they were about the possible uses that others might make of genetic tests.

\section{Other arguments and other positions}

The second type of argument put forward by the judge mentioned above, as well as other opponents to the tests, was of a legal nature. As mentioned previously, French law stipulates that the DNA tests used in the case of traditional DNA profiles must be based on 'non-coding' DNA markers. This is because, until recently, it was believed that non-coding DNA (just like traditional fingerprints) could only allow comparisons between DNA profiles and did not provide any information about the person's physical appearance. According to the company managers, the TOGG technique was legal because it was based on markers found in this noncoding DNA. However, the tests did provide indications about people's origin. For the TOGG's opponents, these tests therefore 'sidestepped the law'. More fundamentally, the principles of this law refer to one particular aspect of DNA that many of my interview respondents underscored, particularly one judge: 'Research into DNA will maybe one day allow us to know whether we're more likely to have a particular kind of illness, to perhaps also have an even more precise idea of our origin, it relates to family secrets. ... There's something internal, something private, about DNA.' This raises the question of the balance between the interests of the legal procedure and the suspect's 'right not to know' (particularly 
characteristics linked to illnesses) (Koops and Schellekens, 2008). In short, while DNA raises issues for actors regarding self, identity, origin, and family (Rose, 2007), the legal framework seeks to provide guarantees from the perceived risks linked to the range of information that could be collected.

The third argument levied against the TOGG by critics related to its reliability, which brings us back to certain aspects mentioned earlier regarding how 'scientific' it was. Interview respondents highlighted the fact that these tests had not been validated by publications in international scientific journals, a criticism that certain social science researchers have also made (Fullwiley, 2011): 'These procedures have never been the subject of a scientific publication in a scientific journal such as Nature with the specific characteristic of having a scientific committee that validates the hypotheses or results put forward by the scientist whose results they publish' said one judge in an interview. Moreover, the validity of genetic analysis in forensics draws upon statistical calculations that are sometimes complex and liable to render some results uncertain (M'charek, 2000). However, this element was not mentioned by the interviewees. At all events, the company's commercial approach meant that it was not in a traditional research situation with peer validation and that its conclusions could not be evaluated with precision. These tests therefore fell under the scope of complex epistemological debates with contradictory effects in terms of legitimacy (they had scientific legitimacy, but this legitimacy was only partial). In other words, the rules for judging what was 'true and false' about the TOGG obeyed their own internal logics (Bacchi, 2012). The tests had an uncertain and ambiguous relationship to the 'truth', which made them all the more problematic.

However, as I mentioned earlier, the judges and prosecutors were not unanimous in their views. During the small meeting in Lyon, aside from the few opponents to the TOGG who were the most vocal, there were also judges I described as 'doubtful' who were less concerned 
with the potentially discriminatory nature of the test. They emphasized that it was not necessarily useful (given that it provided little information), that it was illegal, and that it lacked scientific reliability. As the legal and scientific arguments have already been analysed, I will not go back over them here, but in terms of how useful the tests could be, one judge I interviewed stated, for example: 'Will it really help us in an investigation? ... I don't see how this can be sufficiently precise to direct the investigation'.

Of the judges present at the meeting, two did believe that the TOGG could be useful in helping to identify suspects: one was a young judge who had recently graduated from the French National School for the Judiciary and the other was a former police officer. Another respondent, very highly placed in the institutions at the Ministry of Justice and a former public prosecutor, took the same stance, as she explained in an interview: 'When you start going into: 'What did he look like?', someone will say he's Black. Oh right, he's Black? And so? And so what? Honestly, I can't wait ... for us to have the possibility of using these tests in the same way ... These investigation techniques, this expertise, we shouldn't deprive ourselves of them.' She gave the example of a miscarriage of justice that could perhaps have been avoided with this technique in a case in which she was involved: 'The person who was convicted, it was a guy who was what they call Caucasian, European, a white man. And [the culprit] was a coloured man. He was Black. So therefore with the traces, would we not have been able to determine that [the investigators were barking up the wrong tree]?...' She failed to specify, however, that had DNA traces been available, it would actually have been easier and more reliable to compare DNA profiles than to use a TOGG. Moreover, a judge from Lyon told me that the different investigating judges in France were in email contact and some of them had raised the question of using the test. Another judge explained that this position had to be understood in terms of the million unsolved cases every year in France (a third of the total number of offences) and the desire of the judiciary and police to bring these numbers 
down. However, agreement with the TOGG was much less common among judges and prosecutors than opposition or doubt. It was also less discussed, both in the media and in the interviews I conducted. This discretion on the part of judges in favour of the TOGG can be considered as a result in itself, testifying to the particularly sensitive nature of this technique. One of the specific characteristics of these tests was therefore that they generated divided opinions and, sometimes, difficulty in openly supporting them. It is therefore important to understand the reasons underpinning this difficulty.

\section{The Ministry of Justice and regulations regarding genetic tests}

I will now turn to what Foucault calls 'the development of a domain of acts, practices, and thoughts that seem to pose problems for politics' (Foucault, 1984, p. 384). More specifically, I will look at the stances taken by the state towards the TOGG and how these tests are regulated. We will see why geographic origin based on genetics is a particularly sensitive political issue at the level of the Ministry of Justice.

\section{Calming down a sensitive issue}

Following the publication of the online article mentioned previously, which was also picked up by several newspapers, the Ministry of Justice soon become aware of the affair through the media. Publicly and institutionally, the latter therefore played an important role in the emergence of the problematisation, acting in their traditional capacity as 'gatekeepers' regarding problems emerging in the public arena (Hilgartner and Bosk, 1988). This media attention brought practices to light that, while not widespread, had potentially significant political ramifications. The spokesperson for the Ministry, which took the situation very seriously, immediately alerted the head of the Minister's staff. He explained in an interview: 'This technique was a sensitive issue, it was a potential crisis topic for the Ministry of Justice 
..., which justified proper mobilization of Ministry staff and services to respond in the most appropriate manner possible.' He weighed every word carefully in replying to the journalists' questions: 'According to the information we currently have, it seems that the law has not been broken' and also indicated that an inter-ministry technical committee would take stock of the 'ethical' aspects of the case. In his interview with me, he provided further details about his response. First, he referred to how he expressed it: 'All this was carefully weighed up, calibrated... political cant to some extent, but calming, actually. The idea was to calm things down... The idea was also to say: it looks like there's no problem, but we're still going to check.' Second, he explained its content: 'Practices had evolved and actually the law hadn't anticipated that non-coding DNA could pose problems and could allow a suspect's geographic origin to be determined. The law hadn't anticipated that, so it was legally allowed. ... And yet, from an ethical point of view, we think: it's not great, though, is it?' Somewhat ambiguously, first there was 'no problem' but then there was not only a 'problem' but also an ethical issue. When I asked him to specify in what ways the issue was 'sensitive', he replied: 'It was a sensitive subject, about something that is also full of fantasies, full of irrationality. ... DNA, filing information on the population, ethnicity, those are all dirty words.... There's an extremely sensitive dimension to ethnic origin. There's the notion of Aryan and non-Aryan ... How do I know that people won't look at things [in DNA] that they're not allowed to look at?'

In line with the elements analysed previously, we can see that these tests were a burning issue due to their politically 'sensitive' nature. This was due to the explosive combination of crime, origin (with the question of racism lurking in the background), and DNA (with its potential to reveal information now or in the future). It was also further compounded by the legal framework and the issues related to keeping non-anonymous information on file about populations. However, the debate died down fairly quickly. As the situation seemed to have 
calmed down, the Ministry did not take any other official position for over two years, anxious not to rekindle the controversy: without going as far as 'deconstructing' the problem, it tried to avoid adding fuel to the fire.

\section{Construing points of problematisation in terms of prohibition}

The tests of origin nonetheless remained present in the background. Several people I interviewed confirmed that certain police investigators were definitely interested in using them. One of the managers at company $[\mathrm{X}]$ explained: 'The vast majority of investigators were in favour of these tests, of course they were ... The proof is that they asked us for it. People were prepared to pay fairly substantial sums of money to have this kind of information. Of course they were. And we still regularly receive calls asking: 'Do you do it?' This explains why, in 2010, the Ministry of Justice received an informal request to use these tests from investigators who, according to the head of the Ministry department concerned, were 'important lobbyists'. As well as these informal requests, the Ministry also received an official request from another private company wanting to offer analysis of suspects' physical characteristics. The Ministry therefore took an official position on the matter at this time, after having brought the issue before the relevant commission. The commission members presented a united front with no dissenting voices and concluded that these methods should be considered 'with the utmost caution' for the reasons detailed below. Based on this opinion, the directorate in question published a 'Dépêche' in 2011 - which falls under the remit of what Foucault (1986, p. 12) referred to as 'prescriptive texts written for the purpose of offering rules, opinions, and advice on how to behave as one should'. It did not prohibit using tests of origin as such (a Dépêche is an informative note that does not have the same legal value as a law), but strongly advised against it, which, in practice, came down to the same thing. The main argument was legal. ${ }^{15}$ The text emphasized that these tests fell under the 
domain of 'genetic characteristics' because, rather than identifying an individual like traditional DNA profiles, they could provide information about a person's 'apparent features'. Under French law, genetic characteristics can only be examined for medical purposes or scientific research, which was objectively not the case here. Echoing the words of the tests' promoters, one of the members of the commission explained in an interview: 'The markers used in the TOGG... affect phenotype. If they are used, it's because either they are responsible for, or at least that they are... very close to, a certain number of physical characteristics: eye colour, hair colour, skin colour'. A major 'point of problematisation', to take up Foucault's vocabulary again, and a major point of its regulation is therefore the shift from identifying people to characterizing them by physical appearance. The age-old dream of Galton - the statistician who was disappointed by the use of fingerprints because they allowed criminals to be identified but could not give specific details about their features or affiliation to a group - seems to have now become a reality (Rabinow, 1993).

Moreover, in a less detailed fashion and echoing the words of the members of the judiciary mentioned above, the Dépêche also stipulated that these tests necessarily required using scientific databases ('fichiers') compiled by a laboratory and that, with the information available, it was not possible to 'evaluate how appropriate the measures taken by the laboratory' to obey the law were, 'particularly in terms of making data anonymous' ${ }^{16}$ This Dépêche was based on the law above all and, so far at least, has suspended the use of the TOGG strictly speaking. In all, these tests were used 15 to 20 times in France (see note on recent developments). ${ }^{17}$

To conclude these considerations about the legal situation, political advisement thus provided the 'solution' to the problematisation created by the TOGG and constituted the ministry's 'ethical work' (the way ethics operates, for example through codes or laws) (Dean, 1999). Nonetheless, it is important to note that nearly three years went by between the press article in 
2008 and the Dépêche in 2011 despite the fact that, as the spokesperson for the Ministry stated, it would have been possible to react more swiftly. The question of geo-genetic origin was therefore politically sensitive but, in the absence of any further open controversy, the Ministry of Justice allowed these practices to continue. A period of 'indifferent tolerance' (Gros, 2014) therefore preceded the Dépêche, making the situation slightly more complicated than expected.

\section{Conclusion}

Without claiming that problematisations are rare (Dean, 1999) or, on the contrary, inherent to all policies (Bacchi, 2012), this paper has analysed how different groups of actors (biologists, judges and prosecutors, and political leaders) problematised the question of genetic origin used in a forensic context in the French public space. More broadly, this approach raises the question of how actors " "problematise" what they are, what they do, and the world in which they live' (Foucault, 1986, p. 15): who they are, as professionals, as members of a country with a history, and as members of a species broken down into populations on a genetic basis; what they do, in their capacity as promoters, potential users, or regulators of these tests; and the world in which they live, in terms of a society striving to maintain a balance between ensuring the security of its populations and the dangers of filing information about those populations. One of the key issues here is linked to the idea that understanding the inner workings of problematisation can shed light on the political and moral order of a society - to paraphrase Bowker and Star (2000) writing about so-called racial classification. In this regard, the present study calls for three sets of observations.

The first set relates to how problematisation affects the development of practices in the field of forensic DNA analysis and is based on the fact that the relationship between the TOGG and problematisation is more complex than it seems. My investigation highlighted that these tests 
lie at the intersection between two opposing trends, which create an anthropological 'knot' to paraphrase the term used by Hacking (2005a) to describe a situation resulting from contradictory trends. The first strand to this knot was the strand that 'deproblematised' the issue, as we saw. In this case, it involved three things: (1) the people promoting the tests 'deconstructing the problematisation'; (2) certain judges, prosecutors, and investigators using and requesting the TOGG on the grounds of its usefulness (albeit to a limited extent); (3) political officials allowing a certain amount of time to pass between the 2008 press article and their 2011 Dépêche. The second strand to this knot was the strand that 'problematised' the issue. This problematisation was verbal and operated through the public stances that judges and prosecutors took (on the basis of political/moral, legal, and scientific criteria). It was also institutional, operating through political regulations (on the basis of political/moral and legal criteria). Additionally, the problematisation also included a more interiorized aspect, reflected by the discretion surrounding any use of, or requests for, the tests. Highlighting the existence of this knot offers a way of reaching beyond the notion of prohibition alone or of linear processes in which actors simply provide mechanical solutions to problems.

Nonetheless, as this study has shown, in terms of effects on practices, problematisation won over deproblematisation. It contrived to curb both the development and use of the TOGG in France, whereas it had very little impact on the use of traditional DNA profiles (article in preparation). Furthermore, the difference with the Netherlands, where these kinds of tests of suspects' origin have been legalized, is salient. Interestingly, as M'charek (2008) explains, the arguments which led to them being used in an important criminal case in the Netherlands were ethical and grounded on preventing discrimination against migrants who had been suspected of a crime they had not committed. Discrimination, or countering discrimination, seems to be able to serve both sides of the arguments surrounding these tests, depending on 
the context. Further studies could allow this situation to be analysed in terms of problematisation in other national contexts (Palson and Rabinow, 2005).

My second set of observations relates to changes regarding the notion of origin. The notion of origin may be age-old, but the problems in this case related to how it has started to change. Anyone observing these new practices will have a confused sense that we are not simply witnessing a return to the modes of thinking and acting about origin that prevailed in previous centuries, even though older forms of understanding seem to remain and combine with the new context rather than disappearing completely. First, these tests allowed a particular mode of thinking to persist and develop: one that insists on differences that are passed down from generation to generation and that can be seen on the body. Furthermore, because this information about suspects was provided by DNA, this would seem to establish the idea that 'ethnicity' or 'racial' difference are a biological given rather than above all a sociocultural construct. Finally, we have seen that opponents to the test foregrounded the potential dangers they could present under a more or less authoritarian regime. The issue here - and this was new - was how the databases compiled by laboratories could potentially be used and disseminated, unlike oral eye-witness statements which remain subject to the confidentiality of the criminal investigation. According to Wade (2014), the phenomena that can be described as 'racial' are, on the one hand, based on nature, heredity, and the way in which the latter is expressed in appearance and, on the other hand, grounded in geographical and historical facts. This idea affords us a better understanding of why these new origins are politically and morally sensitive topics, far more so than oral testimonies at any rate. Three components of the history of these racial theories - heredity, appearance, and domination - seem to have recombined in a powerful fashion making the issue an explosive one. The sensitive nature of this new configuration is further compounded by the question of the potential uses of any databases compiled by laboratories. 
Another aspect relating to changes in origins concerns their links with the national context.

Fassin and Fassin (2006) explain that, in the United States, the persistent prevalence of multiculturalism is based on the ideal that all identities should receive equal recognition, including those that are looked down upon or dominated. They add that, in France, issue, as they see it, is recognizing discrimination rather than identities: what 'Blacks' and 'Arabs' (the largest so-called 'minority' groups in France) have in common is not 'race' but racism. The changes shown in this article bring the question of identity back into the discussion. On the basis of molecular and statistical data, the TOGG contributes to the debate about people having a particular identity because they belong to a particular population - a debate that is reshaping the French context to some extent. While this remark relates to a very specific context, more broadly it also shows how the circulation of techno-scientific knowledge can affect how issues are framed: in addition to the traditional forms of racial discrimination that still exist (against 'Blacks' and 'Arabs' for example), the TOGG could potentially create new forms of discrimination based on biological identity and DNA.

A third dimension to these changes related to origin derives from what is considered to be scientifically reliable or not; to use Foucault's vocabulary, the 'play of the true and the false'. These tests are part of a scientific dynamic linked to the fact that, in the twentieth century, the genetic approach became not only one of the leading disciplines in the sciences (Fox Keller 2003) but also a form of knowledge that spread among the population (Vailly, 2013). Stated briefly, practices and politics related to origin have taken a genetic turn. More broadly, these tests actively return to a scientific perspective on issues of identity and origin, an older perspective that nonetheless never completely disappeared in the twentieth century (Brattain, 2007; Skinner, 2006). However, this angle obviously takes a new and very different shape with tests that now call upon molecularization, cutting-edge biomedical techniques, and the participation of commercial biotechnology companies. More generally, molecularizing origin 
not only implies moving from phenotype to genotype, as has sometimes been described in the field of biomedical research (Abu El-Haj, 2007), but also, in this particular case, following the reverse pathway leading from genotype to phenotype. Geneticists therefore move from the molecular body to the physically apparent body, and vice versa, on the basis of geographical origin (i.e. Asia, Africa, etc.). These different political, moral, legal, and epistemic points characterize the changes that have occurred regarding so-called geographic, ethnic, or racial origin and that have been revealed by the problematisation examined in this article. In short, this all illustrates how Foucault's notion of problematisation can add to existing studies of the relationship between genetics and origin, 'ethnicity', or 'race'. ${ }^{18}$ The study I have discussed here contributes to showing how old and new conceptions can be combined, linked, and/or contrasted. It also encourages us to keep in mind that the debates raised by these questions can be taken up by other social actors (in the police, the justice system, or the State) rather than just by scientists, doctors, or the clients who take online tests of origin. Given that research into people's origin is moving out of the arena of laboratories and of clinical practice, this could also encourage study of the social stakes involved not only in how such tests are used but also in the use of databases [fichiers] classifying people according to origin. Moreover, this study has also underlined the importance of contextualizing practices in light of the specific history of individual countries, rather than analysing debates on these questions in terms that are too broad. ${ }^{19}$

Finally, my third and final set of remarks relates to the politics of life science and the analytical framework I chose to apply here. As we saw in the introduction, this framework encourages analysis of the scientific, moral, and political aspects of biopolitics (with particular emphasis on the political, in this case) as well as of the subjects it produces. In this study, different types of subjects and power relations appeared among the different people involved. Those putting forward the tests wanted to be seen as ethical subjects, particularly 
through their Charte; those challenging the tests construed themselves as ethical and political subjects who were mobilizing to put an end to their use; and those regulating the tests construed themselves as ethical and political subjects acting through the law. Moreover, unlike the problematisation of sexuality analysed by Foucault, which brings into play an ethics of self, in the case of the TOGG, an ethics and a politics of society were also at stake. As we have seen, this case did not just question relationships to self, it also questioned relationships to others (Who is the 'Other'? What are we doing collectively?) as well as relationships to the potential uses that others might make of the tests, which is definitely a political issue. By raising the alarm about the possible uses that authoritarian powers could make of genetic files [fichiers], the judges and prosecutors who were against the TOGG resisted processes relating to the biopoliticization of identity (Foucault, 2008 [1979]). Unlike in Rabinow's study (1999) focusing on the conflict between the French laboratory CEPH and the American company Millenium in the 1990s, the challenges here did not mainly come from specialists in bioethics or 'repentant scientists' developing a 'spiritual' dimension regarding 'dignity' or the definition of the person; in this case, the political dimension was much stronger and was clearly expressed as such. In short, above and beyond the particular case discussed in this article, my results suggest that it is important to pay closer attention not just to scientific categories and bioethical debates, but also to the political uses of DNA analysis; not just to the techno-scientific identities of the people being tested, but also to the kinds of subjects that are produced among those promoting and those contesting them.

\section{REFERENCES:}

Abu El-Haj, N. (2007) The Genetic Reinscription of Race. Annual Review of Anthropology 36: $283-300$. 
Bacchi, C. (2012) Why Study Problematizations? Making Politics Visible. Open Journal of Political Science 2(1): 1-8.

Bamshad, M., Wooding, S., Salisbury, B.A. et al. (2004) Deconstructing the Relationship between Genetics and Race. Nature Genetics 5: 598-609.

Berger, P.L. and Luckmann, T. (1966) The Social Construction of Reality: A Treatise in the Sociology of Knowledge. Garden City, New York: Anchor Books.

Bowker, G.C. and Star, S.L. (2000) Sorting Things Out. Classification and its Consequence. Cambridge, London: The MIT Press.

Brattain, M. (2007) Race, Racism and Antiracism: UNESCO and the Politics of Presenting Science to the Postwar Public. American Historical Review 112(5): 1386-1413.

Burchard, E. G., Elad Ziv, N.C. et al. (2003) The Importance of Race and Ethnic Background in Biomedical Research and Clinical Practice. New England Journal of Medicine 348(12): 1170-1175.

Canselier, G. and Desmoulin-Canselier, S. (2011) Les catégories ethnoraciales à l'ère des biotechnologies. Paris: Société de Législation Comparée.

Chapman, H. and Frader, L.L. (2004) Race in France. Interdisciplinary Perspectives on the Politics of Difference. New-York, Oxford, Berghahn Books.

Collins, F.S. (2004) What We Do and Don't Know about 'Race', 'Ethnicity', Genetics and Health at the Dawn of the Genome Era. Nature Genetics Supplement 36: S13-S15.

Cooper, R.S., Kaufman, J.S. and Ward R. (2003) Race and Genomics. New England Journal of Medicine 348(12): 1166-1170.

Deacon, R. (2000) Theory as Practice: Foucault's Concept of Problematization Telos, 118: 127-142.

Dean, M. (1999) Governmentality: Power and Rule in Modern Society. London, Thousand Oaks, New Delhi: SAGE. 
Duster, T. (2011) Ancestry Testing and DNA. Uses, Limits, and Caveat Emptor. In: S. Krimsky and K. Sloan (eds.) Race and the Genetic Revolution. Science, Myth, and Culture. New York: Columbia University Press, pp. 95-115.

Fassin, D. and Fassin, E. (eds.) (2006) De la question sociale à la question raciale. Paris: La Découverte.

Fischer, M.J. (2012) Science. In: D. Fassin (ed.) A Companion to Moral Anthropology. Malden Oxford: Wiley-Blackwell, pp. 395-412.

Foucault, M. (1984) Polemics, Politics and Problematizations. An Interview with Michel Foucault. In: Rabinow P. (ed.) Foucault reader New York. Pantheon Books, pp. 381-390. Foucault, M. (1986) The Use of Pleasure: The History of Sexuality (Vol. 2). New York: Vintage.

Foucault, M. (1989) Foucault Live (Interviews, 1966-84). Lotringer, S. (ed.) New York: Semiotext(e).

Foucault, M. (2008 [1979]) The Birth of Biopolitics: Lectures at the Collège de France, 19781979. London and New York: Palgrave Macmillan.

Foucault, M. (2011 [1978]) The Stage of Philosophy. New York Magazine of Contemporary Art and Philosophy, 1.5, available at http://www.nymagazine.org/PDF/The_Stage_of_Philosophy.html (Accessed June 2015).

Fox, D. (2010) The Second Generation of Racial Profiling. American Journal of Criminal Law 38(1): 49-79.

Fox Keller, E. (2003) The Century of the Gene. Cambridge: Harvard University Press.

Fujimura, J.J. and Rajagopalan, R. (2011) Different Differences: The Use of 'Genetic Ancestry' versus Race in Biomedical Human Genetic Research. Social Studies of Science 4(1): 5-30. 
Fullwiley, D. (2007) Race and Genetics: Attempts to Define the Relationship. BioSocieties 2: 221-237.

Fullwiley, D. (2008) The Biologistical Construction of Race: ‘Admixture' Technology and the New Genetic Medicine. Social Studies of Science 38(5): 695-735.

Fullwiley, D. (2011) Can DNA ‘Witness’ Race?”. In: Krimsky, S., Sloan, K. (eds.) Race and the Genetic Revolution: Science, Myth and Culture New York: Columbia University Press, pp. 116-126.

Garraud, P. (2004) Agenda. In: L. Boussaguet, S. Jacquot, and P. Ravinet (eds.) Dictionnaire des politiques publiques. Paris: Presses de Sciences po, pp. 51-58.

Glaser, B.G. and Strauss A. (1967) The Discovery of Grounded Theory. London: Aldine.

Gros, F. (2014) Problématisation. In: J.-F Bert and J. Lamy (Dir.) Michel Foucault. Un héritage critique, pp. 125-126.

Hacking, I. (2005a) Seminar "Façonner les gens.” Collège de France, Paris.

Hacking, I. (2005b) Why Race Still Matters. Daedalus 134(1): 102-116.

Hilgartner, S. and Bosk, C.L. (1988). The Rise and Fall of Social Problems: A Public Arenas Model. American Journal of Sociology, 94(1): 53-78.

Kahn, J. (2013) Race in a Bottle: The Story of BiDil and Racialized Medicine in a PostGenomic Age. New York: Columbia University Press.

Kayser, M. (2015) Forensic DNA Phenotyping: Predictive Human Appearance from Crime Science Material for Investigative Purposes. Forensic Science International (18): 33-48.

Kingdon, J.W. (1984). Agendas, Alternatives, and Public Policies. Boston, Toronto: Little, Brown and Company.

Koops, B.-J. and Schellekens, M. (2008) Forensic DNA Phenotyping: Regulatory Issues. Science and Technology Law Review Vol IX: 158-202. 
Lemke, T. and Rödel, M. (2011) Les tests ADN dans les procédures d'immigration: les doubles standards de la parenté. In: J. Vailly, J. Kehr, J. Niewöhner (eds). De la vie biologique à la vie sociale. Approches sociologiques et anthropologiques. Paris : La Découverte, pp. 130-158.

Lynch, M. and Mc Nally, R. (2009) Forensic DNA Databases and Biolegality. In: P. Atkinson, P. Glasner and M. Lock (eds) Handbook of Genetics and Society. London, New York: Routledge, pp. 283-301.

Mattelart, A. and Vitalis, A. (2014) Le profilage des populations. Du livret ouvrier au cybercontrôle. Paris : La Découverte.

M'charek, A. (2000) Technologies of Population: Forensic Testing Practices and the Making of Differences and Similarities. Configurations 8(1): 121-158.

M'charek, A. (2005) The Human genome Diversity Project: An Ethnography of Scientific Practice. Cambridge: Cambridge University Press.

M'charek, A. (2008) Silent Witness, Articulate Collective: DNA Evidence and the Inference of Visible Traits. Bioethics 22(9): 519-28.

M'charek, A. (2013) Beyond Fact or Fiction: On the Materiality of Race in Practice. Cultural Anthropology 28(3): 420-442.

M'charek, A., Schramm, K. and Skinner, D. (2014) Technologies of Belonging: The Absent Presence of Race in Europe. Science, Technology, \& Human Values 39(4): 459-467.

Nash, C. (2007) Race and Relatedness in Population Genetics and Genetic Genealogy. In: P. Atkinson, P. Glasner and H. Greenslade (eds.) New Genetics, New Identities. Oxon, New York: Routledge, pp. 77-100.

Ndiaye, P. (2006) Questions de couleur. Histoire, idéologie et pratiques du colorisme. In: D. Fassin and E. Fassin (eds) De la question sociale à la question raciale. Paris: La Découverte, pp. 37-54. 
Nelson, A. (2013) DNA Ethnicity as Black Social Action? Cultural Anthropology 28(3): 527536.

Noiriel, G. (1996) French and Foreigners. In: P. Nora (ed.) Realms of Memory: The Construction of the French past, vol. 1: Conflicts and Divisions. New York Columbia University Press, pp. 275-379.

Noiriel, G. (2006) “Color-blindness” et construction des identités dans l'espace public français. In: D. Fassin and E. Fassin (eds) De la question sociale à la question raciale. Paris: La Découverte, pp. 158-174.

Ossorio, P.N. (2006) About Face: Forensic Genetic testing for Race and Visible Traits. Journal of Law, Medicine and Ethics 34: 277-292.

Ossorio, P. and Duster, T. (2005) Race and Genetics. Controversies in Biomedical, Behavioral, and Forensic Sciences? American Psychologist 60(1): 115-128.

Palson, G. and Rabinow, P. (2005) The Iceland Controversy: Reflections on the Transnational Market of Civic Virtue. In: Ong A., Collier S.J. (eds) Global Assemblages. Technology, Politics and the Ethics as Anthropological Problems. Malden: Blackwell Publishing, pp. 91-103.

Rabinow, P. (1993) Galton's Regret and DNA Typing. Culture, Medicine and Psychiatry, 17(1): 59-65.

Rabinow, P. (1999) French DNA. Chicago: University Chicago Press.

Rabinow, P. and Rose, N. (2003) Foucault today. In: P. Rabinow and N. Rose (eds) The essential Foucault: selections from the Essential Works of Foucault, 1954-1984. New York: New Press.

Raman, S. and Tutton, R. (2010) Life, Science, and Biopower. Science, Technology \& Human Values 35(5): 711-734. 
Readon, J. (2005) Race to the Finish: Identity and Governance in an Age of Genomics. Princeton: Princeton University Press.

Rose, N. (2007) The Politics of Life Itself. Biomedicine, Power and Subjectivity in the TwentyFirst Century. Princeton, Princeton University Press.

Sankar, P. (2010) Forensic DNA Phenotyping: Reinforcing Race in Law Enforcement. In: I. Whitmarsh and D.S. Jones (eds.) What's the Use of Race? Modern Governance and the Biology of difference. Cambridge, London: MIT Press, pp. 49-61.

Sauer, N.J. (1992) Forensic Anthropology and the Concept of Race: If Race don't Exist, Why are Forensic Anthropologists so Good at Identifying Them? Social Science \& Medicine 34(2): 107-111.

Skinner, D. (2006) Racialized Futures: Biologism and the Changing Politics of Identity. Social Studies of Science 36(3): 459-488.

Skinner, D. (2011) Mobile Identities and Fixed Categories: Forensic DNA and the Politics of Racialized Data. In: R. Rottenburg, K. Schramm and D. Skinner (eds) Identity Politics after DNA: Re/creating Categories of Difference and Belonging. Oxford, New-York: Berghahn.

Smart, A., Tutton, R., Martin, P. et al. (2008) The Standardization of Race, Ethnicity in Science Editorials and in UK Biobanks. Social Studies of Science 38(3): 407-423.

Social Studies of Science (2008) Special issue: Race, Genetics, and Disease 38(5).

Toom, V. (2012) Bodies of Science and Law: Forensic DNA Profiling, Biological Bodies, and Biopower. Journal of Law and Society 39(1): 150-166.

Vailly, J. (2006). Genetic screening as a technique of government: the case of neonatal screening for cystic fibrosis in France. Social Science \& Medicine 63(12): 3092-3101.

Vailly, J. (2013). The birth of a genetics policy. Social issues of newborn screening. Farnham: Ashgate. 
Vailly, J., Bellivier, B., Noiville, C., and Rabeharisoa, R. (2016). Les fichiers d'empreintes génétiques et les analyses d'ADN en droit pénal sous le regard du droit et de la sociologie. Cahiers Droits, Sciences \& Technologies (in press).

Wade, P. (2014) Race, Ethnicity, and Technologies of Belonging. Science, Technology, \& Human Values 39(4): 587-596.

Wade, P., Deister, G., Kent, V. et al. (2014) Nation and the Absent Presence of Race in Latin American Genomics. Current Anthropology 55(5): 497-522.

Welch, K. (2007) Black Criminal Stereotypes and Racial Profiling. Journal of Contemporary Criminal Justice 23(3): 276-288.

\footnotetext{
${ }^{1}$ This research benefited from funding from the Université Paris 13, the MSH Paris-Nord and the French National Research Agency (contract: ANR-14-CE29-0014). This text was translated by Lucy Garnier. I am grateful to Milena Jaksic for her participation in the field investigation. I also extend my thanks to Vololona Rabeharisoa for her reading of a previous version of the manuscript and to the anonymous reviewers for their critical reading.

${ }^{2}$ However, studies on genetic tests of origin concerning African Americans as descendants of slaves, or people wanting to obtain information in this field, are developing (see in particular Nash, 2007; Nelson, 2013).

${ }^{3}$ Among the different studies on DNA profiling, see especially M'charek (2000) and Lynch and McNally (2009).

${ }^{4}$ On this topic, see in particular Vailly (2006) and Vailly (2013).

${ }^{5}$ More broadly, it is important to remember that Foucault was both a philosopher and a historian. He therefore always tried to develop theoretical frameworks that were rooted in practice. This is why 'problematisation' refers both to a concept and a historical process.

${ }^{6}$ The most recent is the ministerial order of August 10, 2015.

${ }^{7}$ Art. 706-54 of the French Code of Criminal Procedure.
} 
${ }^{8}$ The French legal system is mainly inquisitorial. The French judicial system includes specialist judges, known as investigating judges (juges d'instruction), who oversee investigations in the most serious and complex offences. His or her role is to gather all the information that may incriminate or exonerate a person accused of an offence. The public prosecutor supervises the criminal investigations department (police judiciaire). He or she exercises criminal proceedings and has strong links with governmental authority in implementing public prosecution policy. Judges and prosecutors are both 'magistrats'. They follow the same training at the same school:

http://www.justice.gouv.fr/art_pix/french_legal_system.pdf

${ }^{9}$ These markers are a variation of a single base at a specific point of the genome (called Single Nucleotide Polymorphism or SNP).

${ }^{10}$ These tests are typical of those based on so-called ancestry markers which evaluate origin on the basis of continental categories used as references and of admixtures of sequences considered as coming from different continents (Fullwiley, 2008).

${ }^{11}$ In the literature, researchers in the social sciences question this scientific dimension (Ossorio and Duster, 2005; M'charek, 2005; Fujimura and Rajagopalan, 2011; Fullwiley, 2011), and the same is also true of geneticists themselves (Bamshad et al,. 2004) who highlight the constructed nature of categories of origin. Conversely, other authors argue that many errors are made in oral testimonies during police and legal investigations, and take a pragmatic approach based on arguments regarding the validity of DNA tests (Fox, 2010). ${ }^{12}$ Even if, as Ndiaye (2006) adds, only very few studies on this subject are available in France.

${ }^{13}$ For another approach to this topic, see Raman and Tutton (2010) and Lemke and Rödel (2011). 
${ }^{14}$ Cf. Jul. 1, 1972 law, supplemented on June 7, 1977 by art. 187-1 and 416 of the French Criminal Code.

${ }^{15}$ Dépêche CRIM-PJ nº8-28.H5 tome 4, dated June 29, 2011.

${ }^{16}$ Law relating to information technology, files, and freedom $n^{\circ} 78-17$.

${ }^{17}$ Very recently a new Decision of the Court of Cassation (Decision $n^{\circ} 3280$, dated June 25, 2014) authorized genetic tests in France to extract not geographical origin but 'apparent morphological features' (colour of eyes, skin or hair, etc.), without specifying which markers were to be used. This will be the topic of a further study, along with the difference in problematisation between the TOGG and these 'apparent morphological features'.

${ }^{18}$ These studies show in particular how geneticists use genetic sequences linked to people's origin in health research, how they challenge (or fail to challenge) the category of 'race' in their practices, how notions of origin are transformed under their influence, and how commercial concerns contribute to these changes (cf. references in introduction).

${ }^{19}$ In this spirit, certain authors have contextualized the question of genetic origin (M'charek et al., 2014; Wade et al., 2014). 